Cezary Józef OLBROMSKI

Katolicki Uniwersytet Lubelski

\title{
Homo figurativus versus homo politicus - rozważania na temat kryzysu polityczności
}

ekst ten przywołuje dwie - z pozoru nie mające ze sobą zbyt wiele
wspólnego - sytuacje kryzysu politycznego oraz kryzysu polityczności. Staram się udowodnić, iż etiologia obu sytuacji kryzysowych związana jest z wyczerpywaniem się paradygmatu demokratycznego. Połączenie instrumentalnego i teleologicznego działania aktorów stanowi o treści mobilizacji, ta zaś jest jedną z podstawowych przyczyn zarówno kryzysów politycznych, jak i kryzysu polityczności.

Zdefiniowania wymaga samo pojęcie kryzysu politycznego. Klasyczne rozumienie kryzysu politycznego jako pewnej koniunktury krytycznej ograniczonej czasowo oraz jako niezwykle dynamicznego procesu zmian społecznych nie wyczerpuje współczesnego znaczenia terminu kryzysu politycznego, bowiem temporalny rozpad relacji ekonomicznych i społecznych przynosi pozytywny efekt zastapienia dotychczasowych relacji przez jednostki uwolnione od dotychczasowych ról społecznych. Dla nowoczesnego kryzysu politycznego znamienne jest strukturalne wpisanie stałej zmiany i stałego rozpadu oraz stałej dyspozycji do zmiany sposobów zachowań i ról społecznych. Tak rozumiany kryzys polityczny, z jakim mamy do czynienia w życiu ekonomicznym i społecznym, jest przyczyną kryzysu polityczności aktorów indywidualnych i zbiorowych. Obie sytuacje mają za podstawę mobilizację społeczną, która, po pierwsze, nie służy już przezwyciężaniu kryzysu czy zwiększeniu udziału politycznego grup do tej pory negatywnie uprzywilejowanych, po drugie, nie stanowi o zwiększeniu skuteczności działań aktorów politycznych, lecz wyraża się w działaniach aktorów politycznych prowadzących do transformacji strumieni komunikacji społecznej oraz, w drugim przypadku, do transformacji logik społecznych w instrumentalnie zracjonalizowanym środowisku społecznym. Mobilizacja nie jest więc w tym przypadku uzyskaniem kontroli nad określonym rodzajem zasobów w relacji do innych podmiotów 
- jak postulował Etzioni ${ }^{1}$ - lecz budowaniem domeny totarientalnej ${ }^{2}$. Ten typ mobilizacji staje się dzisiaj w polityce typem dominującym. Współczesny proces mobilizacji występujący w polityce, pozostającej w stanie permanentnego kryzysu będącego bezpośrednią podstawą kryzysu polityczności, zamienia się w strategię budowania nie tylko wizerunku lidera partii - co niejednokrotnie jest nam dane prześledzić w kampaniach politycznych - lecz również w strategię budowania nowych typów komunikacji społecznej oraz domen dominacji/mobilizacji kontekstowej.

Kolejnym wątkiem mobilizacji społecznej jest jej sterowność. Elementem istotnym jest sterowanie mobilizacjami społecznymi przez aktorów zbiorowych (rządy, grupy interesu etc.). Mobilizacje nie są wypadkowymi działania pojedynczych aktorów społecznych, lecz należy je rozpatrywać w kategoriach podejmowania decyzji ${ }^{3}$. Mobilizacja w dobie kryzysu jest więc zmianą społeczną, której planowy charakter uwidaczniany jest w skuteczności działania. Nie można oczywiście zaprzeczyć, iż spontaniczne i tworzone oddolnie ruchy społeczne realizują cele społeczne, lecz ich skuteczność nie jest determinowana przez reaktywne zachowania indywidualne. Podstawowe znaczenie w takich sytuacjach pełnią działania taktyczne uczestników kryzysu. Elementarne i krótkookresowe działania nie pełnią zasadniczej roli w trwaniu konfliktu, ponieważ nie odwołują się do kontroli zasobów. Spontaniczne demonstracje są skuteczne w kryzysach politycznych jako jedno ze źródeł mobilizacji, ponieważ modelowane są ich wyniki, a nie przebieg. Zamieszki uliczne, spontaniczne demonstracje, protesty, manifestacje, strajki etc. są skuteczne dopiero wówczas, gdy - zabrzmi to trywialnie - osiagają zamierzone cele bądź cele, które miały być osiaggnięte, zostają skutecznie spacyfikowane. Innymi słowy, albo prowadzą one do alokacji zasobów albo utrwalają dotychczasową strukturę zasobów. Opis zjawiska kryzysu będzie tym bardziej adekwatny im precyzyjniej określeni zostaną główni aktorzy wykorzystujący zdarzenia, nie zaś aktorzy kreujący bądź realizujący jakieś zdarzenia. Oczywiście, niejednokrotnie będą to ci sami aktorzy. Zasadnicze znaczenie jednak posiada wartość realizacji celów przez wykorzystanie zdarzeń jako skutków

1 Cf. E. Etzioni, The Active Society. A Theory of Societal and Political Processes, New York 1968, s. 388.

2 Totarientalny $=$ totalny + dezorientujący + bezbiegunowy.

3 Problemy z płynnością finansową Grecji spowodowały reakcję Międzynarodowego Funduszu Walutowego, Unii Europejskiej, rządu Grecji oraz planową mobilizację części społeczeństwa greckiego. 
mobilizacji. Mobilizacja nie jest określana przez podanie źródła energii działania społecznego, jak u Etzioniego ${ }^{4}$, lecz poprzez kontekstowy efekt działania. Posłużmy się przykładem.

1. Efekt protestu/próby mobilizacji przeciwko jakiejś funkcjonującej strukturze zasobów poprzez zniszczenie wodociagów w rejonie, w którym wszystkie/większość nieruchomości posiadają indywidualne studnie, będzie inny aniżeli w rejonie ubogim w wody gruntowe.

2. Efekt próby mobilizacji jakiegoś skompromitowanego - będącego podmiotem afer obyczajowych, którego przedstawiciele cieszą się znacznymi przywilejami prawnymi, ekonomicznymi etc. - związku wyznaniowego będzie inny aniżeli efekt protestu związku wyznaniowego posiadającego autorytet moralny - zakładając oczywiście, iż w odbiorze społecznym wartości humanistyczne posiadają znaczącą wartość.

3. Efekt protestu politycznego, przykładowo konsekwentnej głodówki, jakiegoś opozycjonisty będzie inny, gdy zostanie on medialnie nagłośniony i udostępniony opinii publicznej, aniżeli ograniczony do najbliższego środowiska stanowiącego naturalne zasilenie owego opozycjonisty. Każdy z tych modelowych i niezwykle uproszczonych przykładów odwołuje się do pojęcia kontroli zasobów - każdy z nich w odmienny sposób. Pierwszy, poprzez skuteczne reglamentowanie zasobów koniecznych do fizycznej egzystencji innych aktorów sceny politycznej. Drugi, poprzez wymuszoną interpretację idei, która pełni funkcję perswazyjną wobec otoczenia zewnętrznego i nie stanowi żadnego utrudnienia - pozostawiam tutaj na boku egzystencjalną sprzeczność zachodzącą między kodeksem a działaniem - dla samego związku. Trzeci, poprzez ofiarę z własnego życia. W tym ostatnim przypadku przesłanie protestu odwołuje się do domniemanej wspólnoty wyznawanych wartości, zaś jego oczekiwana skuteczność w postaci mobilizacji zasobów bazuje na wspólnocie wartości i niesymetryczności sytuacji stron.

W każdej z tych sytuacji pozostające do dyspozycji zasoby początkowe znacznie odbiegają od zasobów oczekiwanych i możliwych do uzyskania w nowym rezultacie modelowania.

Zatem pojęcie mobilizacji nie tyle odnosi się do jakiegoś działania społecznego, ile do ograniczonego znaczenia skutków. Poprzez zawężenie pojęcia mobilizacji do służącego osiaganiu celów otrzymujemy ścisły

4 Cf. E. Etzioni, The Active Society. A Theory of Societal and Political Processes, New York 1968, s. 392. 
związek działania społecznego i strategii aktorów politycznych. Mamy więc do czynienia z analizą a posteriori, a dokonując oceny działania kierujemy się nie tyle skutecznością działania, ile adekwatnym i właściwym rezultatem działania $\mathrm{w}$ relacji do zamierzonych efektów. W ocenie bieżących wydarzeń posługujemy się więc historyczną perspektywą pozbawioną w swej retrospektywnej ocenie wydarzeń znamion obiektywności. Widoczne one były w analizach M. Webera, który w Objektive Möglichkeit und adäquate Verursachung in der historischen Kausalbetrachtung pisze:

„Przewaga historyka nad jego bohaterem polega tutaj na tym, iż w każdym przypadku wie on a posteriori czy ocena dokonana przez podmiot na podstawie «zewnętrznych» warunków w zgodzie z jego wiedzą i oczekiwaniami przystaje do faktycznej sytuacji: pokazują to rzeczywiste i ówczesne «skutki» działania. [...] Wyposażony w tego rodzaju instrumentarium historyk stając w miejscu swego «bohatera» mógłby retrospektywnie $-\mathrm{z}$ większym lub mniejszym stopniem pewności - odtworzyć z jeszcze większym sukcesem niż, na przykład, sam von Bismarck odpowiedź na pytanie: jakich następstw należałoby oczekiwać przez podjęcie innej decyzji. [...] Opinia, że skoro, pojedynczy fakt historyczny pomyślany został jako nieobecny w kompleksie historycznych warunków lub jako obecny w zmienionej formie oraz mógłby być przyczyną odmiennego [niż zaistniały] w pewnych określonych, historycznie ważnych relacjach historycznego biegu zdarzeń, zdaje się być istotną wartością w ustaleniu «historycznego znaczenia» tych faktów; jednakże w praktyce historyk może nie mieć okazji świadomie rozwinąc tego sądu i wesprzeć go przy pomocy argumentów w jakimkolwiek lecz ściśle określonym przypadku, szczególnie w takim, który jest przedmiotem sporu na temat «historycznego znaczenia». Jasnym jest, iż okoliczność ta zobowiązuje do rozważenia logicznej istoty opuszczenia lub zmiany pojedynczej komponenty z kompleksu warunków i określenia rezultatu oraz znaczenia dla historii”"

Obiektywistyczne podejście reprezentowane przez Webera, a polegające na skutecznym skorelowaniu wiedzy na temat zdarzeń do ,faktycznej sytuacji” w teorii kryzysu politycznego jest odwrócone. Intencja działania wywołującego określony skutek i idąca w tym kierunku mobilizacja przesądza a priori o charakterze ujęcia fenomenu kryzysu - o działaniu taktycznym. Jednakże mobilizacja nie ogranicza się do samej intencji - nie stanowi statycznej reguły gry konsekwentnie realizowanej. Jeżeli

${ }^{5} \mathrm{M}$. Weber, Objektive Möglichkeit und adäquate Verursachung in der historischen Kausalbetrachtung, s. 287-268. 
odwołamy się do teorii gier, to stwierdzimy, że rozwiązujemy problemy cząstkowe - wykonujemy posunięcia cząstkowe - aktualizując metodę gry poprzez elastyczne modelowanie sytuacji w czasie rzeczywistym. Ta szczególnego rodzaju teoria gier rozumiana jako ciąg posunięć cząstkowych - odpowiedzi na zaistniałe sytuacje - sprawdza się we współczesnej polityce będącej sceną nieustannego kryzysu władzy i legitymizacji. Mamy współcześnie do czynienia z ewolucją gry politycznej możliwej do zobrazowania przez ciąg posunięć cząstkowych. Stosowana konsekwentnie taka taktyka gry politycznej pokazuje, iż zagrożeniem dla polityczności jest stan permanentnej „sytuacji granicznej”. Posunięcia polityków przypominają bowiem ciąg cząstkowych posunięć dokonywanych w czasie rzeczywistym jako odpowiedzi na zewnętrzne problemy, zewnętrznych aktorów ${ }^{6}$.

Uprawianie polityki, które po drugiej wojnie światowej zostało utrwalone w polityce zimnowojennej w postaci taktycznych gier odstraszających zmienia swoje znaczenie. Kreowanie długofalowych taktyk w ramach teorii gier wymuszających postulatywnie przewidywalne zachowania przeciwnika i bezpośrednio wprowadzanych do sytuacji konfliktowej jako jej nieodłączne elementy podtrzymujące konflikt ustąpiło - postulatywnie na stałe - cząstkowym posunięciom dokonywanym w czasie rzeczywistym. Dotychczasowa realność jasno zdefiniowanego przeciwnika uzupełniona jest o realną temporalność perspektywy wyborów. Dotychczasowe post-zimnowojenne techniki podejmowania decyzji opierały się na zapewnieniu sobie bezwzględnej szczelności informacyjnej w dłuższej perspektywie czasowej. Współczesne modelowanie w obrębie domeny

6 Jednym ze sposobów analizy fenomenu tożsamości zbiorowej są metody stosowane przez socjologię historyczną M. Webera. Owe podstawy zajmujące się ludzkimi działaniami w ramach (1) bądź to naturalnie danych, (2) bądź też historycznie określonych warunków traktują swój materiał obserwacyjny jako wyznaczniki, z jednej strony, przyjęte dla działań ludzkich, z drugiej zaś strony, w odniesieniu do ,elementów konieczności": mianowicie - po pierwsze - w naturalnych warunkach ślepej konieczności wydarzeń naturalnych oraz - po drugie - w historycznie określonych warunkach obowiązywalności wspólnych związków [cf. M. Weber, Knies und das Irrationalitätsproblem, s. 44]. Innymi słowy, Weber zadaje pytanie o podstawową relację jaka zachodzi między prawem a rzeczywistością w kontekście upływu czasu historycznego pozostawiając na boku ,ślepą" konieczność zdarzeń naturalnych [cf. M. Weber, Roscher „,historische Methode”, s. 8]. W tekście odnoszę się raczej do przyszłości bazując na analizie zjawisk teraźniejszych w ich konkretnych związkach przyczynowych, aniżeli w kierunku odwrotnym. Nie będę starał się więc, stosując paralelizmy, zwrócić uwagę na nowy typ więzi społecznych powstających w GTI (grupy tematycznej informacji). Cf. mój tekst zatytułowany GTI jako e-polis domeny działań pozapolitycznych. 
polityki skłania raczej do stwierdzenia, iż podstawową taktykąjest ograniczenie przeciwnikowi możliwości wyboru z powodu zdezaktualizowania się określonych możliwych wyborów ze względu na wybranie przeze mnie określonego sposobu działania - posunięcia cząstkowego. Konieczność szczelności informacyjnej skraca się, pełniąc nadal zasadniczą rolę. Skraca się z tego prostego powodu, iż ewolucja posunięć cząstkowych - jej przebieg - wskazuje z dużym prawdopodobieństwem na kolejne posunięcie. Z drugiej jednak strony nieuchronny udział czynnika niedającego się przewidzieć czyni modelowanie dodatkowo przewidywalnym. Przeciwnik jest w stanie wprowadzić nowy czynnik skłaniając gracza do zachowania nie tyle dokładnie zgodnego z oczekiwaniami, co do zachowania przewidywalnego. Jednakże nie teoretyczne abstrahowanie z całości określonych posunięć jest moim celem, lecz pokazanie jak dodatkowe czynniki wpływają na ograniczenie wyboru przeciwnika gry.

Powraca więc element intencjonalności działania leżącego u podstaw zachowań politycznych - ciągu posunięć cząstkowych - które nie pozostają ukierunkowane tylko na prowadzenie ciagłej gry/eliminacji posunięć przeciwnika, lecz realizację założonych celów. Ograniczona przewidywalność efektów posunięć cząstkowych wzmocniona przez eliminację konkretnych zachowań/posunięć przeciwnika przewidywanych a priori jest ważna z punktu intencjonalności podejmowanych działań. Jednakże teleologiczna w istocie taktyka realizacji własnych celów politycznych jest de facto ograniczona przez continuum zmian środowiska i konieczności bieżącego dostosowania posunięć cząstkowych do nowych warunków. Przykładowo, z natury swojej pozapolityczne problemy techniczne koncernu BP związane z zatamowaniem wycieku ropy naftowej z szybu w Zatoce Meksykańskiej niosą doniosłe pozaekonomiczne skutki. Wraz z tymi skutkami są przyczyną konieczności korygowania politycznych posunięć cząstkowych. Podobnie dzieje się w przypadku blokady strefy Gazy przez Izrael. Potraktowanie konwojów z pomocą humanitarną przez państwo Izrael i medialne nagłośnienie tego zdarzenia ponownie zwróciło uwagę opinii publicznej na problem palestyński. Oba przywołane przed chwilą przypadki wskazują z pewnością na konieczność rezygnacji z relacji kooperacji czystej na rzecz dążenia do sytuacji - niemożliwej zresztą do osiągnięcia - rozwiązywania konfliktów w ramach gry o sumie zerowej ${ }^{7}$.

Niemożliwość osiągnięcia zwycięstwa przy pomocy metod gry o sumie zerowej spowodowana jest wzajemnymi powiązaniami gospodarek i państw, ekonomicznych i politycznych stref wpływu etc. 
Teza ta wydawać się może zbyt radykalna, lecz zdaje się adekwatnie opisywać dążenia stron konfliktu politycznego. O ile w przypadku indywidualnych aktorów niemal niemożliwe są do przewidzenia ich indywidualne intencje - bogaty nurt Verstehen obecny w naukach społecznych dobrze pokazuje jak trudno jest to uczynić - o tyle analiza zachowań aktorów zbiorowych podejmujących działania w ramach gry o sumie zerowej jest wdzięcznym przedmiotem analizy ${ }^{8}$. Optymizm w formułowaniu takiego sądu jest jednak ograniczony przez totarientalność współczesnej sceny politycznej. Nawet tak jednoznaczne i drastyczne działania jak blokada konwojów z pomocą humanitarną dla strefy Gazy - jeżeli nawet intencjonalnie miały prowadzić do całkowitego rozwiązania problemu w ramach gry o sumie zerowej - nie są intencjonalnie skuteczne. Zatem intencjonalne ukierunkowanie działania wywołującego określony skutek, idąca w tym kierunku mobilizacja skorygowane będą o efekt totarientalności przesądzający a priori o mieszanym charakterze działania taktycznego.

Pozostaje jeszcze jedna kwestia, na którą zwrócił uwagę Dobry ${ }^{9}$. Mianowicie działania aktorów zbiorowych o charakterze ciagu posunięć cząstkowych nie wyczerpują się tylko jako działania kontestujące posunięcia władzy lub skierowane przeciwko istniejącemu porządkowi politycznemu. Dobry stawia w opozycji ,instytucje kontroli społecznej” i mobilizację wskazując na opozycję między działaniem zbiorowym a uciskiem. Polemizować można czy przywołane przez niego Smelsera rozróżnienie działań instytucjonalnych i zachowań zachowuje swoją ważność

8 Odsyłam w tym momencie do dwóch artykułów Maxa Webera, do R. Stammlers «Überwindung» der materialistischen Geschichtsauffassung, s. 342 oraz do Objektive Möglichkeit und adäquate Verursachung in der historischen Kausalbetrachtung. W tym ostatnim artykule Weber pisze (s. 280-282): „Nie będzie koniecznym wyjaśniać dalej przy pomocy skomplikowanych przykładów powszechnej obowiązywalności tych zdań ani wyraźnie stwierdzać, iż nasza logiczna procedura jest dokładnie taka sama w analizach decyzji Napoleona lub von Bismarcka, jak w przypadku niemieckiej matki w podanym [wyżej] przykładzie. Differentia specifica, iż „głębia” jej czynów przez nas analizowanych jest dana w jej pamięci, podczas gdy my musimy „zinterpretować” działanie trzeciej osoby ,z zewnątrz” jest - wbrew naiwnemu sądowi - jedynie różnicą stopnia dostępności i kompletności „materiału”. Jesteśmy wówczas nieustannie zmuszeni wierzyć, znajdując „osobowość” jakiegoś człowieka zawiłą i trudną do wyjaśnienia, iż on sam jest w stanie, zapewniając jedynie o swojej uczciwości, udzielić na ten temat rozstrzygającej informacji." Nie jest to wszakże - jak dalej pisze Weber - możliwe. Oba teksty pochodzą ze zbioru pism metodologicznych zatytułowanych Gesammelte Aufsätze zur Wissenschaftslehre (tłumaczenie autora).

9 Cf. M. Dobry, Socjologia kryzysów politycznych, s. 22. 
w otoczeniu totarientalnym oraz czy sytuacja konfliktu da się jednoznacznie opisać przy pomocy takiego przeciwstawienia. Współczesna sfera polityczna sprzęgnięta mocno z gospodarką wskazuje raczej na konieczność analizy sektorowej - dokładniej - na interpretację posunięć cząstkowych aktorów poprzez odwołanie się do mechanizmu kreowania domen ${ }^{10}$. Grupy tematycznej informacji posługują się przy tworzeniu domen turbulentnie zmienianymi aksjomatami, których porażająca moc obowiązywalności nie daje jednak pewności postępowania. Ich siła polega na pierwszeństwie bądź tematycznej wyłączności dysponowania informacją i kreowaniu ciągu posunięć cząstkowych w obrębie domeny totarientalnej, w ramach której mamy do czynienia z kontekstową obowiązywalnością tematyczną informacji.

Powracamy zatem do jednej z zasadniczych tez, wedle której aktorzy grupowi intencjonalnie dążą do wytworzenia sytuacji gry o sumie zerowej, celowi temu służą wysiłki monopolizacji domen w taki sposób, iż domena, w której GTI posiada wyłączność jest rozszerzana przy nieulegających w zasadzie warunkach początkowych dotyczących jej imponderabiliów. Owo dążenie do totarientalizmu jest czymś znacznie bardziej radykalnym aniżeli osiaganie poprzez wykluczanie polityczne konkurencyjnych idei jednomyślności - pomimo podobieństwa tej ostatniej do techniki uprzedzania i eliminowania określonych wyborów przez posunięcia cząstkowe. Jednomyślność bowiem jest zbiorową odpowiedzią aktorów jednostkowych na konsekwentne zastosowanie techniki mobilizacji zasobów w kontekście konkretnych preferencji tych aktorów. Poszerzanie domeny totarientalności natomiast jest związane z próbą zmiany istoty otoczenia i nośników jej sensu. Owo poszerzanie jest próbą zastąpienia mechanizmów społecznych stechnicyzowanymi procesami komunikacyjnej skuteczności służących już nie uzyskaniu poparcia społecznego dla podejmowanych przedsięwzięć, lecz wprzęgnięcia aktorów indywidualnych w sferę egzystencjalnej konieczności. Zracjonalizowane instrumentalnie/formalnie kalkulacje - rozumiane bynajmniej nie jako podstawa indywidualnych aktorów - zajmują miejsce odwoływania się do preferencji społecznych.

10 Zwraca na to uwagę Mączyński pisząc: „ważne jest przypomnienie, że złożoność interakcji świata techniki i reszty naszego świata wymaga do opisu zaangażowania innej logiki niż zwykła logika konstrukcji myślowych [...]. Istnieje bowiem inna logika, logika gry, logika interakcji niezależnych podmiotów. Rządzi nią użyteczność, a nie zwykła prawda lub fałsz. Jak już była mowa, przegrywa najsłabszy, milczący." Jacek F. Mączyński, O racjonalności technicznej dyskusyjnie, s. 72. 
Tym skuteczniejsze jest działanie GTI im bardziej ograniczona jest sfera społeczna i socjalna.

Zatem proponowane ujęcie intencjonalności dotyczące mobilizacji oraz mobilizacji zasobów rozważane w kontekście kryzysu politycznego prowadzi do wniosku, iż wystapienie kryzysu politycznego niekoniecznie spowodowane jest destrukcyjnym działaniem niezadowolonych bez względu na ich umiejscowienie na scenie politycznej. Nowoczesny kryzys - z wpisaną $\mathrm{w}$ system polityczny przy pomocy zabiegów legislacyjnych opozycją polityczną - niekoniecznie powodować musi destrukcję systemu, jego wymiary oddziaływania niekoniecznie dotyczą sfery władzy - jej kontestacji - oraz politycznego status quo. Nowoczesny wymiar kryzysu politycznego nie wyczerpuje się - tutaj zgadzam się z M. Dobrym ${ }^{11}$ - w opozycji ,instytucji kontroli społecznej” i mobilizacji. Jaka jest więc natura i zasadnicza rola kryzysów we współczesnej sferze zjawisk społecznych? Teza, której będę bronił dotyczy wykorzystania kryzysu sfery politycznej/społecznej jako pozytywnego katalizatora zmian. Takie ujęcie roli kryzysu politycznego wiąże się z koniecznością przedefiniowania niektórych pojęć i wskazania na nowy kontekst interakcji społecznych.

1. Na początku należy zwrócić uwagę na postępujący proces biurokratyzacji sfery polityczności. Formalizacja stosunków politycznych ma służyć - wedle reformatorów sfery polityki i elit - tworzeniu bogatego zbioru zestandaryzowanych zachowań politycznych. Powodem, dla którego podejmuje się takie wysiłki jest zwiększenie skuteczności oddziaływania politycznego i przewidywalności podejmowanych działań. Paradoksalnie, tego rodzaju tendencja służy eliminowaniu sfery polityczności z relacji społecznych. Dodatkowo należy zwrócić uwagę, iż postępujący proces biurokratyzacji sfery polityczności ${ }^{12}$ należy odróżnić od samoodniesienia aktorów sfery politycznej przezwyciężających niezwykle trudne dzisiaj do przyjęcia posługiwanie się ideologiąjako sposobem kształtowania tożsamości zbiorowej. Zbyt dynamiczny model ideologicznego budowania tożsamości grupowej - historia sporów religijnych, ideologicznych oraz

11 Cf. M. Dobry, Socjologia kryzysów politycznych, s. 22.

12 Odsyłam w tym momencie do licznych opracowań krytycznie odnoszących się do roli UE w regulowaniu sfery polityczności jako procedur postępowania ograniczających się tylko do standaryzowania zachowań politycznych, a w dalszej kolejności do zestandaryzowanych zachowań politycznych. Oddzielną kwestią jest praktyka inplantów i transplantów prawnych - metody, niejednokrotnie, ułomnego regulowania legislacyjnego. 
wydarzenie totalitaryzmów XX wieku jednoznacznie przesądzają o tym, iż ideologia zbytnio obciąża posiadane zasoby i działa destrukcyjnie - zastąpiony zostaje pragmatyką oraz świadomym kształtowaniem e-środowiska społecznego. Zatem przeciwieństwem pozornie atrakcyjnego procesu biurokratyzacji jest samoodniesienie aktorów - także grupowych - i twórcze kształtowanie przestrzeni społecznej.

2. Konsekwencją tego jest drastyczne ograniczenie działań politycznych w klasycznym rozumieniu tego terminu. Współczesne wpływy technokratów na proces sprawowania władzy ukierunkowują także polityczność zadaniowo - to znaczy transformacja sfery politycznej przebiegająca równolegle do (razem z) procesów ekonomicznych posługuje się kryzysem jako narzędziem politycznym - nie mogąc go zniwelować wpisuje kryzys w sferę swoich działań.

3. Kryzys jest nie tylko czymś ostatecznie wpisanym w sferę polityczną. Jest on także nieodłączną częścią GTI i jej struktury, co w dalszej części zostanie rozwinięte.

4. Wskazanie na przeciwieństwo procesu biurokratyzacji i twórczego kształtowania przestrzeni społecznej jako stechnicyzowanego myślenia kryzysowego nie wyczerpuje zagadnienia racjonalizacji formalnej. Nowym wyzwaniem jest konieczność tworzenia elastycznego systemu narzędzi teoretycznych służących przewidywalności posunięć politycznych GTI. Dynamiczny model walki i chwilowej dominacji ideologicznej zastępowany jest przez dynamiczny model elastycznego poszukiwania w połączeniu ze statyczną wyłącznością. Wyłączność jest tutaj rozumiana jako wyłączność inicjatywy decyzyjnej ośrodka oraz jako kreowanie rzeczywistości w ramach domeny decyzyjnej. Totarientalność przejawia się w tym momencie w multiplikacji aktora posiadającego wyłączność w domenie oraz w zawłaszczanych przez domeny tematach. Innymi słowy, wielość niezwiązanych ze sobą centrów decyzyjnych stara się rozszerzyć własne domeny obowiązywalności zasad i reguł. Heterogeniczność systemu falsyfikuje na bieżąco statyczną wyłączność. Posługiwanie się kryzysem jako narzędziem działania w sferze społecznej wzmacnia dodatkowo heterogeniczność systemu. Najtrudniejszym zadaniem, ale także zadaniem, którego spełnienie przyniesie największy sukces jest skuteczna homogenizacja systemu - wymuszenie uznania przez wszystkie GTI reguł, a tym samym ich powszechna obowiązywalność.

5. Zatem jednym z najbardziej palących zadań jest obiektywizacja stosunków GTI oraz stosunków sektorowych. Służy ona, po pierwsze, zwiększeniu przewidywalności w systemie i stabilizacji systemu, po dru- 
gie, poddaniu kontroli procesu przewidywalności podejmowania decyzji politycznych. Jawi się zatem obraz mocno zinstytucjonalizowanego systemu GTI, które w obrębie swoich domen powinny - w interesie przetrwania domeny - podejmować adekwatne do otoczenia zewnętrznego działania. Idealnym typem takiego zachowania jest rozszerzanie domeny w heterogenicznym środowisku GTI aż do zawłaszczenia sfery społecznej jako homogenicznej domeny GTI. Konsekwencje takiego stanowiska są wielorakie. Przede wszystkim mamy do czynienia ze środowiskiem nietransparentnym, którego wartość z punktu widzenia standardów demokratycznych jest niska. Zatem podążanie od heterogeniczności GTI w kierunku homogeniczności systemu jest procesem de-demokratyzacji.

Jednym z najsłabszych elementów tego systemu zasługującym w tym miejscu na uwagę jest sposób, w jaki mobilizowane będzie zaplecze/zasoby. Problem związany z przekonywaniem zasobów GTI do gry realizowane przez GTI odbywa się w ten sposób, iż tory materiałowe/fizyczne wypierane są przez tory informacyjne. Kryzys polityczny wykorzystywany jest jako narzędzie poprzez odwoływanie się w działaniu politycznym do bardzo wąskiej tematycznie informacji, której niezbędność oznajmiana jest w procesie komunikacji między GTI a systemem oraz w ramach GTI. Klasyczne rozumienie lojalności jako skłonności do wykorzystywania określonych zasobów w razie decyzji innych ${ }^{13}$ zastępowane jest przez samotransformację indywidualnych aktorów kreujących domenę bądź też wykorzystywane jest w sposób wskazujący na bardzo wąskie rozumienie terminu lojalność, którego desygnatem wydaje się być wywołanie czysto zewnętrznej reakcji zasobów pokrywającej się z oczekiwaniami. Dlatego też-z punktu widzenia spójności GTI jako systemu - najbardziej korzystnym wydaje się przestrzeganie zasady, iż nie ten wygrywa kto jest najlepszy w gromadzeniu zasobów, lecz ten kto jako pierwszy - pierwszeństwo jest tutaj warunkiem wyłączności - osiagnie określony stan ${ }^{14}$. Zatem dy-

13 Cf. C. Tilly, From Mobilization to Revolution, s. 71.

$14 \mathrm{~W}$ pierwszym przypadku dominuje podejście tradycyjne i czysto ilościowe traktujące jako wyznacznik ,sukcesu” skuteczność w gromadzeniu zasobów. W drugim przypadku chodzi o skokowe i jakościowe rozszerzenie domeny. Innymi słowy, mamy do czynienia z dwoma kryteriami: ilościowym i jakościowym. Różnica między - czysto ilościowym - osiagnnięciem mety jako pierwszy w zawodach sportowych a mobilizacją zasobów materiałowych/informacyjnych dających pierwszeństwo polega na różnicy warunków początkowych. W biegu sportowym można być drugim, w procesie rozszerzenie domeny można być GTI kreującą domenę bądź GTI, która znajdzie się w sferze wpływów domeny - nie można być drugim. 
namiczny model walki zastępowany jest przez dynamiczny model elastycznego poszukiwania w połączeniu z momentami statycznej wyłączności przesądzającymi o skuteczności działań, jednakże turbulentność systemu falsyfikuje na bieżąco statyczną wyłączność.

6. Skoncentruję się na analizie typu idealnego systemu oddziaływań GTI, który to system uchwycony jest w określonym momencie. Wcześniej czysto ilościowe wyznaczniki skuteczności gromadzenia zasobów i działania będące miarą „sukcesu” przeciwstawiłem skokowemu i jakościowemu rozszerzeniu domeny GTI - pierwszeństwo przeciwstawiłem wyłączności. Wypada temu poświęcić kilka słów komentarza. Nowa teoria modelowania $\mathrm{w}$ szczególnych okolicznościach przybierająca postać

Przywołam w tym momencie wydarzenia Okrągłego Stołu 1989 roku. GTI-1 rozpoczynające proces dzielenia się władzą polityczną w drodze mobilizacji posiadanych zasobów starało się zneutralizować mobilizację zasobów GTI-2 poprzez zdelegalizowanie nieposłuszeństwa wobec domeny utrzymywanej przez GTI-1. Pomysł delegalizacji realizowany przez GTI-1 stanowił formę neutralizacji skuteczności mobilizacji GTI-2. Będzie to znacznym uproszczeniem, ale przyjmijmy, iż proces dzielenia się władzą rozpoczął się w roku 1980, która to cezura czasowa może być traktowana jako zdarzenie inicjujące. Stan wojenny 1981/1982 był ostatnią próbą radykalnego zneutralizowania przez GTI-1 domeny, której posiadania GTI-2 była już w pełni świadoma. Dalsze procesy transformacyjne były procesem oswajania GTI-2 z przetransformowaną domeną GTI-1. Znaczący udział GTI-2 nie stanowił zagrożenia dla celów domeny GTI-1, ponieważ to GTI-1 była pierwsza w rozumieniu jakościowym. Subiektywnie rozumiane zwycięstwo GTI-2 było przede wszystkim znaczącym wynikiem dla GTI-1 - było to podleganie wpływom Pierwszego Świata i neutralizacja skutków coraz bardziej niewygodnego dyskursu ideologicznego. Powrót określonej grupy, nazwijmy ją GTI-x do dyskursu ideologicznego był - w niewielkim uproszczeniu - zwierciadlanym odbiciem, puszczeniem taśmy do tyłu, tego, co obowiązywało w czasach monopolu GTI-1. Patrząc z perspektywy lat, które nastapily po 1989 roku, domena GTI-1 rozszerzona znacznie o dawną domenę GTI-2 na tyle ewoluowała, iż niemal fanatyczna mobilizacja GTI-x nieuzupełniona żadną informacją tematyzującą domenę skazana była na regres w demokratycznym środowisku społecznym stanowiącym GTI nadrzędną wobec GTI-1 i GTI-2 i homogenizującą całą przestrzeń społeczną. Z samej definicji GTI może rozszerzać/utrzymywać domenę tylko dzięki informacji. GTI korzystająca z mobilizacji zasobów metodą wywoływania resentymentu i pozbawionej pozytywnego przesłania skazana jest na zanik znacznie szybszy niż demograficzny zanik zasobów.

Te marginalne z punktu widzenia tematu zasadniczego rozważania prowadzą jednak do zasadniczych wniosków. Kardynalnej ważności nabiera zagadnienie przywództwa. Do tej pory rozważanego jedynie w przypadku dużych sformalizowanych grup GTI stają się swoistymi jądrami kondensacyjnymi mobilizacji osiaganej przy pomocy technik skuteczności „,informacyjnej” i ,znaczeniowej” ewaluowanej przez jednostki związane $\mathrm{z}$ domeną GTI. 
teorii mobilizacji może być sprowadzona do prostej zasady: nie ten wygrywa kto walczy, lecz ten kto jest posiadaczem. Z pozoru zdanie to jest zdaniem bezsensownym, ponieważ proces zdobywania dominacji przeciwstawiony jest stanowi posiadania, który może być wynikiem owej walki, a nie jej metodą. Ten kto jest posiadaczem, oznacza tutaj wyłączne dysponowanie informacją potrzebną do utrzymania/rozszerzenia domeny. Dynamiczny model walki w wymiarze ilościowym i liniowym ${ }^{15}$ ustępuje miejsca modelowi elastycznego i rozproszonego poszukiwania w totarientalności w połączeniu z efektem statycznej wyłączności. Nowy typ środowiska społecznego zdominowany przez utechnicznione procesy komunikowania się i zdobywania wiedzy, jakim jest e-środowisko (środowisko sieciowo-cyfrowe) zawęża sferę polityczności - sferę działań politycznych - ograniczając w ten sposób ich znaczenie. Innymi słowy, nowy wymiar polityczności budowany jest w coraz większym stopniu w oparciu o zinstrumentalizowaną sferę działania GTI oraz przez nowy typ odniesienia do sfery wspólnotowości bazujący na rozproszonym charakterze zasobów w totarientalnym środowisku. System wydaje się być na tyle systemem rozproszonym, iż wyznacza on jednostkom rolę przypadkowego elementu beztożsamościowo uczestniczącego w rywalizacji między GTI. Wartość nadrzędną posiada kalkulacja aktorów GTI traktująca totarientalną przestrzeń społeczną jako środowisko dla uniwersalnego rozprzestrzeniania określonego typu działań umocowanych w płynnych regułach scalających GTI. Proces ten stanowi o nowego typu legitymizacji w obrębie GTI wypierającej konsekwentnie klasycznie rozumianą legitymizację polityczną. Nowy typ środowiska społecznego zdominowany jest przez techniczne procesy komunikowania się i zdobywania wiedzy ${ }^{16}$. Totarientalność wydaje się być skuteczniejsza od totalności, gdyż proces budowania tożsamości indywidualnej opiera się na zinstrumentalizowanej sferze działania GTI. Nowy typ wspólnotowości - słowo to użyte jest tylko po to, aby opisać mnogość jednostek, nie zaś ich wzajemne relacje ${ }^{17}$ - wprowadza do

15 Tradycyjna liniowość procesu zdobywania przewagi politycznej/władzy/przywództwa określana jest przez obowiązywanie prostego schematu mobilizacji centrum - zaplecze oraz unieważnienia temporalnej komponenty, która dopiero w GTI nabiera ważności (pisałem o tym wcześniej).

${ }^{16}$ Zdobywanie wiedzy jest tutaj rozumiane także jako modelowanie informacją wedle reguł GTI stanowiących podstawę ich wewnętrznej legitymizacji.

${ }^{17}$ Cf. Simmela podział na Gemeischaft i Gesellschaft jest podziałem niewystarczającym. Społeczeństwo nie jest już grupą o rozluźnionych relacjach społecznych, lecz zbiorowiskiem jednostek w relacji do reguł modelowania obowiązujących w GTI. 
sfery polityczności nowego typu tożsamość indywidualną związaną tylko z zinstrumentalizowaną domeną działania GTI porządkująca, wedle reguł wewnętrznej spójności GTI, fragmenty ogólnej totarientalności. Gdyby analizować ów model działania statycznie GTI szybko przestałoby istnieć, gdyby założyć przystosowywanie się GTI do totarientalności - z samej natury totarientalności to wynika - również, jedynie ekspansja domeny GTI i jej reguł umożliwia, chwilowo, skuteczne poruszanie się w totarientalnym środowisku ${ }^{18}$ - zwiększając przy tym stopień totarientalności. Homo figurativus jest kreowany przez GTI jako odpowiadający jej domenie homunculus, od którego oczekuje się kontekstowej/domenowej skuteczności w działaniu.

Homo figurativus jest więc figura. Figura ta nie jest poddawana - na poziomie metateoretycznych analiz skuteczności - ilościowej ocenie skuteczności działania, lecz stanowi jakościowy wymiar GTI. Kontekst mobilizacji społecznej określony jest przez jakościowy wymiar procesów społecznych nie zaś przez czysto ilościowe ujęcie w postaci zagregowanych danych. Stosunkowo niewielka ważność aspektu ilościowego nie polega na niedoskonałości narzędzi ilościowych - w dużym uproszczeniu można powiedzieć, iż ze statystycznego punktu widzenia bocian jest szary; z wyjątkiem bociana czarnego - lecz na przyjęciu teoretycznych modeli, które za podstawę analiz przyjmują ilościowe wyznaczniki, które niestety są na tyle uwikłane w konkretny kontekst wydarzeń/wydarzenia politycznego, iż możliwość ich weryfikacji nie wydaje się możliwa. Przykładowo, trudno byłoby określić minimalną liczbę uczestników manifestacji, która przekładałaby się na skuteczność w kontekście mobilizacji politycznej. Podobnie trudno byłoby określić minimalną ilość wystąpień deputowanego w parlamencie, aby określić skuteczność polityka etc.

Nie przekreśla to wszakże tego, iż relacje wewnątrzgrupowe nie są zadane przez reguły modelowania obowiązujące w GTI.

18 Traktowanie ekspansji domeny GTI i jej reguł jako modelu wzorcowego nie chroni przed nieskutecznością sposobów postępowania i kryzysem GTI. Z całą pewnościąjednak zawsze przyczynia się do zaniku więzi społecznych na rzecz jednostkowych relacji do reguł modelowania właściwych dla GTI. O ile społeczeństwo wydaje się być w relacji do wspólnoty w stanie anomii, o tyle zbiory beztożsamościowych jednostek pozostających w relacji do GTI nie byłyby po prostu zbiorami jednostek w stanie całkowitego rozpadu relacji interpersonalnych, lecz instrumentalnie kreowaną kolekcją tworzoną w celu pragmatycznego opanowania zadań domeny poruszającej się w sferze totarientalności. Homo figuratus - człowiek modelowany - dzięki ekspansji domen GTI zawłaszcza sferę, nad którą panował do tej pory homo policus. 
A już z pewnością karkołomnym zadaniem wydaje się przeniesienie tych ilościowych wyznaczników do innej sytuacji rozważanej jako przyczyna mobilizacji ${ }^{19}$. Innym błędem popełnianym w trakcie analizy pojęcia mobilizacji - nie tak wszakże powszechnym - jest odwoływanie się do podobieństwa regulacji prawnych obowiązujących w dwóch różnych domenach polityczności jako przyczyny bądź jako aktywnego kontekstu określonego typu mobilizacji politycznej ${ }^{20}$. Wydaje się, iż przyjęcie takich metod postępowania w sytuacji niekontrolowanej - niekoniecznie jako sytuacji granicznej, które to pojęcie bliskie jest pojęciu stosowanemu przez C. Schmitta - mobilizacji zasobów.

Zatem homo figurativus nie jest wyrażalny ilościowo. Ani implementacja, ani transplanty prawne, ani wreszcie myślenie indukcyjne nie wyrażaja modelowania informacją stanowiącego zasadniczy sens GTI. Domena

19 Posłużyłem się przykładem czysto elementarnego rodzaju analizy ilościowej. Poziomów takiej analizy - jak się wydaje równie nieskutecznej - jest znacznie więcej. Czy miałoby sens określenie stopnia wpływu politycznego partii tworzących pierwszy sejm III RP na podstawie ilościowej analizy posiadanych przez nie mandatów? Czy miałoby sens analizowanie realizacji politycznych celów zbiorowych przy pomocy wydatków finansowych na nie poniesionych? W kontekście terminu mobilizacji politycznej z pewnością nie, co nie przekreśla skuteczności tej metody jako narzędzia służącego określeniu efektywności działań.

${ }^{20} \mathrm{Z}$ pewnością w niektórych przypadkach taka korelacja faktycznie ma miejsce. Oddzielnym zagadnieniem są transplanty prawne, czyli praktyka bezpośredniego przenoszenia wzorców i instytucji prawnych obowiązujących w jednym systemie prawnym - w dojrzałym i sprawnie działającym systemie prawnym któregoś z państw zachodnich - do systemów prawnych nowych demokracji bądź quasi demokracji. Działanie takie jest pochodną, po pierwsze, myślenia w kategoriach ilościowych, po drugie, myślenia indukcyjnego. W pierwszym przypadku - niewątpliwie realna - statystycznie mierzona skuteczność regulacji prawnych w systemie macierzystym jest przyczyną inkorporowania konkretnych regulacji prawnych bądź ich zbiorów do innych systemów, co niejednokrotnie jest przyczyną sprzeczności w obrębie systemu, do którego regulacje prawne są inkorporowane [na temat problemów ze skutecznością działania regulacji prawnych w niektórych demokracjach i quasi demokracjach cf. Emma Phillips, The War on Civil Law? The Common Law As a Proxy For the Global Ambition of Law and Economics, „Wisconsin International Law Journal”, Wisconsin 2007]. W drugim zaś implementowanie gotowych wzorców - przykładowo: związanych z zastosowaniem strategii marketingu politycznego; stosowanych przez zespoły eksperckie jako poprawiających kondycję gospodarczą rozwiązań ekonomicznych; procedur postępowania w sytuacjach kryzysowych etc. - do innego kontekstu kulturowego i politycznego. W obu przypadkach ze względu na wartości bądź cele zbiorowe - szeroko rozumiany interes społeczny - przyjmuje się, nie kierując się kryteriami jakościowymi, sprawdzające się w innym kontekście społecznym rozwiązania. 
GTI nie jest domeną ilościową, którą można trwale określić za pomocą zobiektywizowanej konstelacji zdarzeń społecznych i obiektywnie obowiązujących wskaźników. Sfera mobilizacji społecznej nie jest zatem wymodelowanym trwale konglomeratem zmiennych i kontekstów. Klasyczne rozumienie mobilizacji zakłada sprawowanie kontroli nad mobilizacją przez jej inicjatorów. Schemat inicjacyjny w momencie rozwijania się jakiegoś działania społecznego stanowiącego jej podstawę przenoszony jest w miarę rozwoju mobilizacji na kolejne sfery przez nią objęte. Owo klasyczne rozumienie niesie za sobą szereg konsekwencji. Wymieńmy kilka $\mathrm{z}$ nich.

Po pierwsze - jak to już zostało zauważone, do kolejnych etapów ewoluującej mobilizacji przenoszony jest niemal niezmienny schemat inicjacyjny, który determinuje dalsze postępowanie i wyniki mobilizacji en $b_{l o c}{ }^{21}$. W tego rodzaju interpretację wpisuje się Dobry pisząc:

21 Jest to widoczne na przykładzie zmian ustrojowych dokonujących się w Polsce w 1989 r. Aktorzy owej mobilizacji wykazywali tendencję do posługiwania się niezmiennymi znacznikami sensu, dzięki którym otoczenie identyfikowało przynależność aktorów do określonych obozów. Od samego początku mobilizacji dominowało myślenie historyczne, zgodnie z którym odwoływano się nieustannie do tych samych schematów, do tego samego bagażu ideologicznego. Początkowe wydarzenia tej mobilizacji (lipiec/sierpień 1980 r.) - postulaty płacowe, socjalne etc. przeniesione zostały - co prawda w formie już przeformułowanej - do dalszych sfer objętych działaniem aktorów. W zasadzie jedynie aktorzy indywidualni stanowiący późniejszą Unię Wolności - także reformatorskie kręgi ówczesnej lewicy - starali się przezwyciężyć początkowe czysto socjalne i ideologiczne nastawienie stron propagowanie idei państwa wybudowanego na bazie początkowego schematu mobilizacyjnego. Chodziło tym aktorom już nie o skonsumowanie i transformację zdobyczy socjalnych i ideologicznych, lecz o transformację modernizacji, która owe zdobycze wykreowała w państwo obywatelskie stanowiące całkowicie odmienną jakość niż początkowe efekty mobilizacji. Kolejne dwadzieścia lat politycznej historii Polski to ścieranie się w niewielkim stopniu zideologizowanego skrzydła proobywatelskiego i proreformatorskiego - analizowanego w kontekście idei państwa nowoczesnego - ze skrajnie zideologizowanym skrzydłem tkwiącym mentalnie w gospodarce nakazowo-rozdzielczej i realnie nie mającym nic wspólnego z intencją mobilizacji lipca/sierpnia 1980 roku. Podział polskiej sceny politycznej dokonany w kontekście wizji i roli państwa pokazuje jak kreowanie teraźniejszości i odniesienie do przyszłości przeciwstawione jest zawłaszczaniu teraźniejszości przez bezwzględną i instrumentalną konsumpcję historii. Widoczne to było także w kampanii prezydenckiej 2010 roku, w której dwaj główni aktorzy - reprezentant stronnictwa reform kreujących nowoczesne państwo ze społeczeństwem obywatelskim w tle oraz reprezentant o bardziej konserwatywnych poglądach używający starej retoryki, której rezerwuarem była (dzisiaj ze względu na obiektywne okoliczności całkowicie nieaktualna) ideologia wyklucza- 
„Teorie te [centralistyczne teorie procesów mobilizacyjnych - C.J.O.] opierają się nie tylko na racjonalizacjach dokonanych przez aktorów. W gruncie rzeczy są one zastępowane intelektualną rutyną specjalistów, historyków lub socjologów, zwłaszcza zaś czysto akademickim wymaganiem 'syntetycznego' przedstawienia wydarzeń. Pociaga to za sobą poszukiwanie i przyznawanie jednolitego sensu zjawiskom - szczególnie mobilizacjom, będącym częścią składową 'kryzysów' - które swoje (często) niepewne i (zawsze) zmienne granice znajdują jedynie w 'biegu' wydarzeń, czyli w kolejno wykonywanych posunięciach, w ich rezultatach" ${ }^{\prime 2}$.

Analizując klasyczne rozumienie mobilizacji zauważamy więc dwa sposoby interpretowania tego fenomenu: a) ze względu na przebieg oraz b) ze względu na skutki.

Po drugie, czysto formalna ocena racjonalności działań związana jest z lojalnością w systemie rozumianą jako skłonność do wykorzystywania określonych zasobów w razie decyzji innych ${ }^{23}$. Sztywne rozumienie mobilizacji jako procesu aplikowania sztywnego schematu inicjacyjnego określa precyzyjnie - niestety zawężając to pojęcie - sferę lojalności i czyni z niej lojalność czysto mechaniczną ograniczającą się bądź to do formalnego zastosowania stosownego schematu zachowania - w przypadku mobilizacji rozumianej jako proces/zbiór historycznych zdarzeń - bądź też do wywołania określonego rodzaju skutków - w przypadku oceny mobilizacji przez pryzmat skutków i rezultatów. Sfera lojalności jest więc typem kontroli nad mobilizacją (w obu jej klasycznych znaczeniach) poprzez ścisłe określenie nie tyle tego, co jest korzystne dla samego procesu, ile poprzez określenie tego, co mieści się w formalnych ramach znaczeń sztywnego schematu inicjacyjnego z jednej strony, bądź, z drugiej, ewaluowana ex post w kontekście skutków. Obie wersje mobilizacji nabierają znaczenia Goffmanowskiej gry napiętej, w której zasadniczą rolę odgrywają interakcje między aktorami mobilizacji.

nia aktorów niemieszczących się w jednowymiarowej wizji ręcznie sterowanego - okazali się zwolennikami dwóch różnych podstaw legitymizacji. Pomijam w tym momencie inne, nieodwołalnie nasuwające się wnioski jak chociażby ten, iż podział polskiej sceny politycznej na lewicę i prawicę ma stosunkowo ograniczone znaczenie etc. Cf. przebogatą literaturę naukową oraz artykuły prasowe poświęcone temu fenomenowi.

22 M. Dobry, Socjologia kryzysów politycznych, s. 30.

23 Cf. wyżej zamieszczone dane bibliograficzne dotyczące tej definicji lojalności. 
Po trzecie, to, że schemat inicjacyjny w momencie rozwijania się jakiegoś działania społecznego stanowiącego podstawę mobilizacji przenoszony jest w miarę jej rozwoju na kolejne sfery przez nią objęte przesądza o charakterze późniejszego procesu decyzyjnego. Sztywny schemat inicjacyjny wyznacza kierunek komunikacji społecznej. Pamiętać należy, iż stanowi ona podstawę procesu modernizacji jako tożsamościowej weryfikacji działania. Natomiast ewaluacja mobilizacji w kontekście efektów/skutków działania nie jest ściśle związana z typem podjętych działań bowiem ocena ta dokonywana jest przez pryzmat skutków decyzyjnych. Na pozór schemat nie wydaje się być tak sztywny jak w pierwszym przypadku. Należy jednak zwrócić uwagę na fakt, iż w ocenie tej nadal najważniejsze są elementy pierwotnego schematu inicjacyjnego. Zatem możliwości dostosowawcze także tego typu mobilizacji są znikome. W obu przypadkach ewentualne korzyści wynikające z elastyczności rozwijania mobilizacji w kierunku skorygowanym są neutralizowane przez założenia/schematy inicjacyjne. W obu wariantach klasycznego podejścia do sytuacji wyjściowej polegającego na braku niemal jakiejkolwiek zmiany, skrajnie ograniczone możliwości adaptacyjne systemu - w zasadzie ich brak - przesądzają o nieadekwatnym do nakładów stopniu powodzenia działania.

Zatem homo figurativus jest kreowany przez GTI jako odpowiadający jej domenie homunculus, od którego oczekuje się kontekstowej/domenowej skuteczności w działaniu i to on odpowiedzialny jest za kryzysy polityczności.

\section{Bibliografia}

Dobry M., Socjologia kryzysów politycznych, Wydawnictwo Naukowe PWN, Warszawa 1995.

Etzioni A., The Active Society. A Theory of Societal and Political Processes, New York 1968.

Mączyński J. F., O racjonalności technicznej dyskusyjnie, „Transformacje” 1998, nr 1-4 (15-18), s. 71-76.

Phillips E., The War on Civil Law? The Common Law As a Proxy For the Global Ambition of Law and Economics, „Wisconsin International Law Journal”, Wiscon$\sin 2007$.

Tilly Ch., From Mobilization to Revolution, Reading, Massachusetts 1978.

Weber M., Knies und das Irrationalitätsproblem, w: M. Weber, Gesammelte Aufsätze zur Wissenschaftslehre, J. C. B. Mohr, Tübingen 1973, s. 42-105. 
Weber M., Objektive Möglichkeit und adäquate Verursachung in der historischen Kausalbetrachtung, Gesammelte Aufsätze zur Wissenschaftslehre, J. C. B. Mohr, Tübingen 1973, s. 146-214.

Weber M., R. Stammlers «Überwindung» der materialistischen Geschichtsauffassung, Gesammelte Aufsätze zur Wissenschaftslehre, J. C. B. Mohr, Tübingen 1973, s. 291-359.

Weber M., Roscher „, historische Methode”, Gesammelte Aufsätze zur Wissenschaftslehre, J. C. B. Mohr, Tübingen 1973, s. 3-42.

\section{Summary}

The paper refers to two apparently unrelated situations, that of a political crisis and a crisis of politicality. The author attempts to provide evidence for the fact that the etiology of these crisis situations is related to the democratic paradigm being exhausted. The combination of the instrumental and teleological activity of the actors is decisive for the content of mobilization, which is one of the fundamental reasons for both political crises and the crisis of politicality. 
